This paper reports a seminal study whose relevance and significance are related to strengthening the importance of improving the distribution policy by introducing a model for optimizing the allocation of budget funds in the decision-making process. It has been determined that the potential of life support of the population in a region (PLSP in a region) acts as a tool for examining the resources in the region in terms of their capability to meet the needs of the population of the region in the current period and in the future. Based on the anthropocentric approach, it was determined that the main strategic resource is human potential that possesses a set of characteristics (components), which reflect its physical potential, the potential abilities and knowledge, as well as property potential. The implementation of the PLSP concept in the region has caused an urgent desire to study modern problems related to the budget and tax management of regional development, specifically, the management of budget expenditures at the stage of their allocation using modern means for supporting these processes. The expediency of using models of mathematical programming to determine the effective structure of the budget, taking into consideration the rate of inflation and the use of the methodology for calculating real wages, has been established. The following values for most priority areas of budget financing were calculated: the level of development of social infrastructure (11\%), the level of vocational training (29\%), the level of remuneration and entrepreneurial income (21\%), and the level of social payments to the population (14\%). It has been found that when a new allocation of budget funds is implemented, the value of the achieved level of PLSP development in a region could increase by $9 \%$ compared to 2021.

The proposed approach is a permanently important prerequisite for the formation of priority areas of budget financing for the components of $P L S P$ in a region in the process of producing and implementing universal and specific solutions in the field of budget and tax management

Keywords: allocation policy, optimal distribution, potential of life support of the population in a region, budget and tax management

$\square$ $\square$
UDC 336.02

DOI: $10.15587 / 1729-4061.2022 .253072$

\section{DEVISING THE POLICY OF FUNDS ALLOCATION IN THE DECISION-MAKING PROCESS UNDER THE BUDGET AND TAX MANAGEMENT}

\author{
Nataliia Kuzmynchuk \\ Corresponding author \\ Doctor of Economic Sciences, Professor \\ Department of Marketing and Management \\ of Foreign Economic Activity* \\ E-mail: nkuzminchuk@karazin.ua \\ Nataliia Mardus \\ Doctor of Economic Sciences, Professor** \\ O leksandr Davydov \\ $\mathrm{PhD}$, Associate Professor \\ Department of Finance and Credit* \\ Viktoria Yevtushenko \\ $\mathrm{PhD}$, Associate Professor \\ Department of Marketing and Management \\ of Foreign Economic Activity* \\ O le na Mele n \\ $\mathrm{PhD}$, Associate Professor ** \\ Alla Kharchenko \\ $\mathrm{PhD}$, Associate Professor \\ Department of Marketing $* \star *$ \\ *V. N. Karazin Kharkiv National University \\ Svobody sq., 4, Kharkiv, Ukraine, 61022 \\ **Department of Accounting and Finance*** \\ ***National Technical University \\ "Kharkiv Polytechnic Institute" \\ Kyrpychova str., 2, Kharkiv, Ukraine, 61002
}

Received date 05.01.2022 Accepted date 15.02.2022 Published date 28.02.2022
How to Cite: G.,Kuzmynchuk, N., Mardus, N., Davydov, O., Yevtushenko, V., Melen, O., Kharchenko, A. (2022). Formation of the policy of the funds distribution in the decision-making process under the budget and tax administration. Eastern-European Journal of Enterprise Technologies, 1 (13 (115)), 69-79. doi: https://doi.org/10.15587/1729-4061.2022.253072

\section{Introduction}

Society is a holistic social organization of human life, which has historically arisen and is constantly developing; it is a system of various relationships that mutually lead to each other. Each independent state is interested in the progressive development and prosperity of its society, in the new quality of which the features and characteristics that will determine its development for the coming decades are increasingly manifested.
The importance of this for the well-being and consciousness of people is growing in the face of destabilization of the economic development of countries due to the global financial crisis caused by the coronavirus pandemic and the restrictive measures. The situation in the energy market, political and socio-economic transformations on a global scale also require qualitative transformations at the strategic and tactical levels of management decision-making.

Adverse trends in the development of the potential for life support of the population of any country are evidenced 
by studies and ratings conducted by both specialists of research institutes and international organizations. For example, according to the UN, the value of the human development index in the world is extremely uneven, which indicates the different achievements of countries in terms of health, education, and actual incomes of the population (Table 1).

The results of the study show that human development is improving but the pace is slowing down in all regions of the world and progress is very unsustainable [1].

Table 1

Human Development Index 2020

\begin{tabular}{|c|c|c|}
\hline Score & Country & $\begin{array}{c}\text { Human Development } \\
\text { Index }\end{array}$ \\
\hline 1 & Norway & 0.957 \\
\hline 2 & Ireland & 0.955 \\
\hline 3 & Switzerland & 0.955 \\
\hline 4 & Hong Kong & 0.949 \\
\hline 5 & Iceland & 0.949 \\
\hline 74 & Ukraine & 0.779 \\
\hline 185 & South Sudan & 0.433 \\
\hline 187 & Chad & 0.398 \\
\hline 188 & Central African Republic & 0.397 \\
\hline 189 & Niger & 0.394 \\
\hline
\end{tabular}

Therefore, the actualization of the issue of improving the socio-economic standards of life of the population based on qualitative transformations in all spheres of life of the country creates conditions for the existence of society and its constant development in modern realities. Objective diagnosis of life support of the population of the country (region) is not only the primary need of the economy. It can be considered as a key indicator of the results of the work of public administration and local self-government bodies both at the level of the country and its regions. Each country includes different territories, districts, regions but they are united by the desire to achieve a high level of life support for the population through the effective allocation of budget funds.

One of the main factors in the stability of the positive economic trends achieved in a country (region) is to ensure economic growth as a basis for improving the well-being of the population. This is possible based on mobilization and effective use of a set of means, among which budgetary tools occupy a significant place. At the same time, the key problem is to ensure the processes of formation of the revenue side of budgets of different levels. On the other hand, the allocation of budget funds, their volume and structure have a significant impact on both individual industries and the country's economy as a whole.

At the strategic level, the effective allocation of budget funds makes it possible to solve the following tasks for the development of the potential for life support of the population:

- stimulating fertility and carrying out an effective migration policy;

- reducing the incidence of the population, ensuring living conditions of the population, improving the environmental situation;

- ensuring employment and growth of incomes of the population, development of knowledge-intensive innovative industries.

However, the current policy of allocation of budgetary funds does not always make it possible to achieve the goals due to the imperfection of existing algorithms of activities to regulate the level of life support potential. As the experience of world leaders shows, the goal of the development of society should not be the accumulation of material goods but the comprehensive development of human abilities and the most complete satisfaction of his/her needs. These phenomena are reflected in the concept of human potential, specifically the anthropocentric approach, the essence of which is manifested in shifting the emphasis from increasing GDP production to the development of human capital. Taking into consideration the degree of priority of expenditures based on an anthropocentric approach would make it possible to concentrate efforts in areas where achieving positive structural shifts is the impetus for appropriate renewal and development in related or more distant areas.

At the same time, the potential of budget and tax management in the structure of state regulation of socio-economic development in many countries of the world is not fully realized. All this predetermines the extraordinary relevance and importance of research into the effective allocation of budget funds in the context of the implementation of strategic tasks to ensure the sustainable development of regions and the country as a whole.

\section{Literature review and problem statement}

Undoubtedly, the main goal of the study of the development of the potential for life support of the population of the region should be to find ways to optimally distribute budget funds. This is necessary to coordinate the adoption and implementation of balanced management decisions, which could create the basis for a purposeful, systematic, and adequate action to ensure the improvement of the quality of life. The need for optimal distribution of budget funds under the items of financing is due, first of all, to the limited resources and the need for their effective use. In addition, at present, in the process of making management decisions in the field of distribution of budgetary funds, a clear and regulated approach has not been formed, which requires its comprehensive study and theoretical justification. Thus, among the main problems with sources of financing of budget programs, the uneven distribution of budget funds over time, space, and among fund managers is highlighted in [2]. As a result, there is a need not only to deepen the level of adaptation of existing theoretical provisions to the realities of the Ukrainian economy but also to develop recommendations for a holistic concept of improving the Ukrainian system of state regulation of regional development.

Paper [3] reports the results of the study on solving the problem of building an effective budget policy. The researchers note that stimulating budget and tax processes is to carry out incentive measures for the subjects of the region's activities. However, there are unresolved issues related to the search for ways to optimize budget expenditures, which indicates a limited analysis of structural and organizational measures in this direction. However, we believe that the meaning and nature of the implementation of any measures should be preceded by the establishment of rational quantitative proportions of the allocation of budget funds.

Study [4] shows that in the budget sphere there is a priority provision of financial resources to budgetary institutions, which during the reporting period had a positive effect on their use. In order to stimulate taxpayers, the state 
provides tax benefits, tax credits, establishes other preferences. By creating features or preferential tax regimes, local authorities attract additional investments, promote new construction, develop foreign economic relations, create special economic zones and industrial construction zones.

However, issues related to determining the dependence of the amount of budget financing of selected areas and trends in the development of the region remained unresolved. The reason for this may be objective difficulties associated with the complexity and inconsistency of the regulatory framework for regulating the tax sphere. The option of overcoming the relevant difficulties may be to substantiate the foundations of state regulation of the region's development with financial and budgetary instruments, which includes the stages of the development process and is a system of interrelated tasks of the region as a socio-economic system.

This approach is applied in [5]; however, the assessment of the level of impact of budget expenditures on the indicators of the potential for life support of the population of the region does not take into consideration the quantitative and qualitative aspects of its measurement.

In this direction, paper [6] is very meaningful [6], in which the optimal distribution of funds makes it possible to achieve an appropriate state of socio-economic development in the region. This indicator is characterized by minimally possible differences in the level of development of the region under study and the ideal region. That is the condition under which the integrated index of socio-economic development of the region reaches maximum values [7]. The main disadvantage of that approach is the difficulty of identifying the characteristics of an ideal region since the socio-economic development of individual territories is influenced by both objective and subjective factors.

Some researchers offer an overly complex apparatus for studying the optimal allocation of budget funds by directions, which is a certain obstacle to the use of the achieved research results by a wide audience of readers [8]. For example, paper [9] proposes methods for modeling the policy of distribution of funds and factors of influence based on the theory of fuzzy sets. In work [10], when studying the budget and tax management, a method of the main components and multifactorial correlation analysis are used. However, given a certain limitation of statistical data, the results of this kind of research have an insufficient level of validity of the level of development of the potential for life support of the population.

When simulating the optimal allocation of budget funds among the directions of development of a region, the approach proposed in [11] was used in the general form. The author has chosen a system of criteria that make it possible to assess the effectiveness of regional management (additive and multiplicative criterion). The limitation of that approach is the impossibility of objectively determining the adequacy of the selected criteria.

On this basis, a model for optimizing the process of distribution of budget funds in the form of a two-criterion problem of nonlinear programming is proposed. The proposed approach makes it possible to investigate the relationship between the level of development achieved through budget allocations in a particular area aimed at solving specific problems of the region's development and the amount of funds to increase it by 0.01 . It is undoubted that this dependence takes an exponential form, that is, the growth of the direction of development of the region is the result of an increase in budget funds aimed at financing this direction.

However, the provisions presented in [11] are debatable from the point of view of the need for an analysis based on real statistical information and the need to take into consideration the level of impact of budget expenditures on the indicators of life support of the population of the region.

The above allows us to argue that it is expedient to conduct a study on the need to devise approaches to modeling the policy of allocation of budget funds. Determining the optimal structure of budget expenditures could improve the level of life support of the population of the region of the country in the process of budget management.

\section{The aim and objectives of the study}

The purpose of this study is to devise approaches to modeling the policy of allocation of funds in order to increase the overall efficiency and effectiveness of management decision-making in the budget and tax management. This would make it possible to form priority areas of financing at the expense of budget funds of certain spheres and objects of budget and tax regulation to improve the level of development of life support for the population of both the country and its regions.

To accomplish the aim, the following tasks have been set:

- to propose a methodical approach to determining the potential of life support of the population (PLSP) as a tool for studying the ability of the region's resources to meet the needs of the population in the current period and perspective;

- to propose a scientific and practical approach to devising a methodology for the effective allocation of budget funds according to the indicators of PLSP in the region.

\section{The study materials and methods}

The methodological basis of this study was the concepts of socio-economic development, state regulation of regional development in the context of the transformation of the financial and budgetary system, the use of financial and budgetary tools for the formation of the potential for life support of the population of the region.

During the study, the method of structural and logical analysis was used to build the logic and structure of the study. Systematization of the researchers' points of view on the content of the basic concepts used in assessing the potential of life support of the population in the region was carried out using the method of theoretical generalization.

Statistical analysis was used to determine institutional trends and the effectiveness of the region's development in the study of the potential of life support of the population, mathematical programming - to optimize the allocation of budget funds for the development of the life support potential of the population of the region. For a visual representation of the obtained results and schematic construction of justified approaches, a graphic method was used. The process of determining the optimal structure of budget expenditures based on mathematical programming was carried out using the RTS Mathcad 14 software (USA). 


\section{The results of studying the optimal allocation of funds in the decision- making process in the budget and tax administration}

\section{1. Determining the potential of life support of the population in a region}

The main disadvantage of the structure of the expenditure part of the state budget is that the formation and implementation of most budget expenditures do not take into consideration the tax capacity of the economy and the population in the process of ensuring budget revenues. This leads to structural imbalances in the state finances and significant (hidden and existing) budget deficits [12]. Another negative factor is the nature of its implementation. Most budget expenditures are aimed not at achieving long-term goals but at solving accumulated problems [13].

The main strategic resource in the regions is human capital, which is influenced by certain factors, namely the level of education, the state of healthcare, the social environment, the standard of living of the population, the environmental situation [14]. Therefore, it can be argued that the characteristics in question form human potential, which has the following components: socio-demographic, social, economic, environmental. Human resources are traditionally used to achieve goals both at the

level of the individual and at the level of society as a whole. These, in addition to instrumental ones aimed at ensuring basic living conditions, include existential ones, providing for the expansion of opportunities and potentials of the individual in the process of self-realization.

Improving the life support of the population of any country simultaneously creates conditions for the existence of society and for its development [15]. PLSP in a region consists of resources of socio-economic potential, providing opportunities to receive salaries and income from business activities. In addition, PLSP includes budget resources in terms of social assistance and pensions, budget infrastructure resources that allow people to receive free benefits. The concept of PLSP in a region is a tool for examining the ability of resources to meet the needs of the population now and in the future. Therefore, the concept of PLSP in a region is based on an anthropocentric approach, which significantly expands the possibilities of a person's free choice of directions for realizing his/her potential, that is, his/her own abilities in various fields. Human capital needs constant development, and this requires significant investments. At the macro level, its financing takes place at the expense of the State Budget of Ukraine. Thus, there is a problem of optimal allocation of limited resources, which can be considered as a problem of mathematical programming since this scientific area considers the use of mathematical methods for solving optimization economic problems [16-18]. The study has formed a methodical approach to the definition of PLSP in a region and its components (Fig. 1).
The potential of life support of the population in this study is understood as a set of fundamental abilities, capabilities of the individual, the level of development and implementation of which increases the productivity of his/her activities. PLSP in a region is to consider the available regional resources that form the incomes of the population in the form of wages, social assistance, pensions, and entrepreneurial income, as well as resources of the budget infrastructure for providing the population with free benefits. PLSP in a region are resources of socio-economic potential in terms of providing opportunities for obtaining wages and income from business activities. In addition, the components of PLSP are budget resources in terms of providing social assistance and pensions, as well as resources of budget infrastructure in the context of opportunities for providing free benefits to the population. Therefore, this study proposes to highlight the following components of it: physical potential, the potential of abilities and knowledge, property potential formed at the expense of budget expenditures. Consider in detail each component and indicators that form it.

The first component of PLSP in a region is the physical potential, which is characterized by socio-demographic factors and health factors.

It is proposed to use the following indicators to assess the state of the healthcare sector: the level of morbidity of the population $\left(x_{1}\right)$ and the level of recovery and sports training $\left(x_{3}\right)$. To assess the social environment - the level of development of social infrastructure $\left(x_{2}\right)$ and the level of housing and communal services $\left(x_{4}\right)$, to assess the environmental situation in the region - the level of environmental safety $\left(\mathrm{x}_{5}\right)$. 
The next component is the potential of abilities and knowledge, which characterizes the knowledge and skills that have been acquired through education, professional training, and cultural development of the individual. To assess it, it is proposed to use the following indicators - the level of education $\left(x_{6}\right)$, the level of culture $\left(x_{7}\right)$.

The final component is the property potential, which characterizes the ability of the individual to rationally and efficiently use the financial resources at his/her disposal to improve the quality of his/her life. To assess it, it is proposed to use the following indicators - the level of remuneration and entrepreneurial income $\left(x_{8}\right)$, the level of social payments to the population $\left(x_{9}\right)$.

Thus, it is possible to attribute the relevant item of expenditure to each of the nine directions $\left(x_{1}-x_{9}\right)$.

5. 2. Devising a methodology for the effective allocation of budget funds according to the indicators of the potential for life support of the population in a region

The process of defining the optimal structure of budget expenditures on the basis of mathematical programming is proposed to be divided into several stages:

Stage 1. Acquire initial information for modeling. To achieve this goal, we use the scorecard, which is justified in the previous chapter. Thus, using the built optimization model, the problem of the most effective distribution of funds will be solved, which will improve the level of PLSP in a region.

As a variable model $y_{i}, i=\overline{1, m}$, the share of funds invested in the $i$-th direction of PLSP development in a region was chosen. Therefore, there is the following constraint:

$$
\sum_{i=1}^{m} y_{i}=1
$$

which takes into consideration that the budget must be distributed among all components of the PLSP in a region, namely the physical potential, the potential of abilities and knowledge, and the property potential of life support of the population of the region.

The amount of money invested in the $i$-th direction:

$$
P_{i}=y_{i} \cdot P_{b}, \quad i=\overline{1, m}
$$

where $P_{b}$ is the total amount of budget funds planned to be invested in the PLSP in a region.

The achieved level of life support for the population of the Kharkiv region will be denoted as $P^{a}$. Even blondes understand we are talking about improving this value by solving the optimization problem of redistribution of budget funds. That is, it is necessary to solve the problem of maximizing the level of PLSP in the region taking into consideration restriction (1). To this end, one needs to build an objective function that reflects the dependence of PLSP in the region on its components, that is, it takes the following form:

$$
I=F\left(x_{1}, x_{2} \ldots x_{9}\right) \text {. }
$$

Thus, to construct the function of dependence of the PLSP level in the region on components, the calculated data for indicators $\left(x_{1}-x_{9}\right)$ over the analyzed period of 2010-2020 were used $[19,20]$. When carrying out the relevant calculations, statistical data on budget expenditures were adjusted taking into consideration the rate of inflation, which made it possible to determine their real value based on the use of the methodology for calculating real wages given in [21].

Since the components of PLSP in a region are measured using different values that vary in different ranges, they were normalized. This process assumes that their values are in the range of 0 to 1 , with the best values of indicators corresponding to 1 , and the worst -0 .

In turn, the value of each indicator $x_{i}$ depends on the financial resources directed in the chosen direction, that is, $x_{i}$ is a function of the following general type:

$$
x_{i}=f_{i}\left(y_{i}\right)
$$

Thus, it becomes necessary to build appropriate functions (models) of the dependence of the components of the level of development of PLSP in a region on the amount of budget funds aimed at the development of the region.

Stage 2. Construction of models of interconnection between the values of indicators that characterize PLSP in the region and the amount of budget funds aimed at its development.

To build models of the dependence of the components of the level of physical potential on the amount of budget funds, the data generated at the previous stage were used. However, we consider it appropriate to add the following consideration: the value of any component $\mathrm{x}_{i}$ will not accept a zero value even if funds are not invested in this direction.

The dependence of indicators that characterize the physical potential $\left(x_{1}-x_{5}\right)$ on the amount of funds from the budget is shown in Fig. 2, 3.

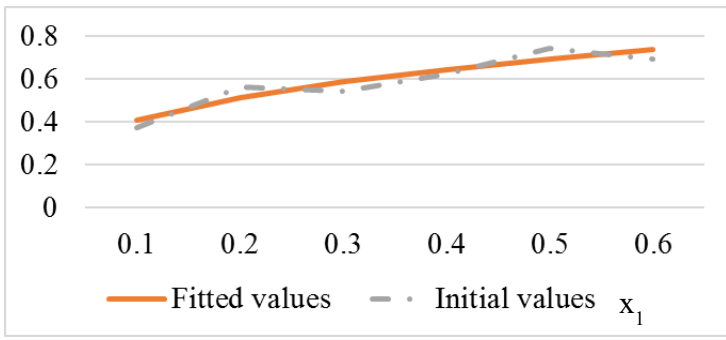

$a$

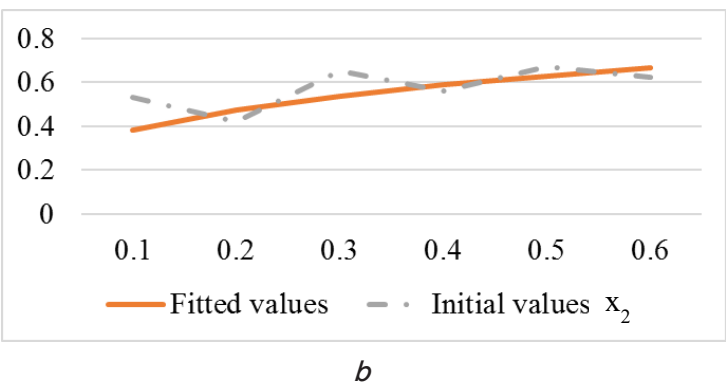

Fig. 2. Normalized values of indicators of the physical potential of the region depending on the amount of funds from the budget in a given area: $a$ - the relative level of morbidity of the population; $b-$ the relative level of development of social infrastructure

Note: compiled by authors using data from [19, 20]

Based on Fig. 1, we can introduce the hypothesis that the relationship between the components of the level of physical potential of the region and the amount of budget funds for their financing can be described by a model of the following form: 


$$
I_{i}=a \cdot y_{i}^{b}
$$

where $a$ and $b$ are the model parameters.

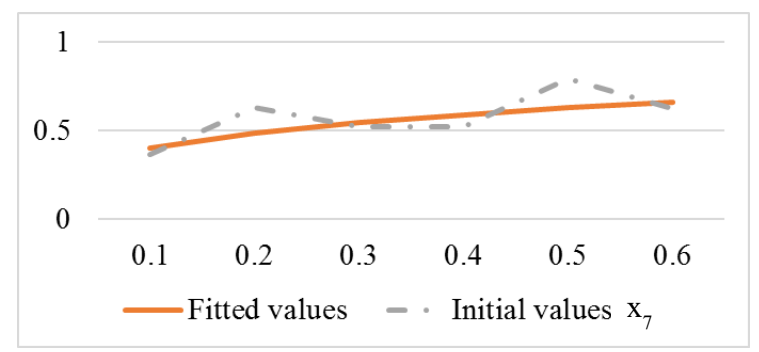

$a$

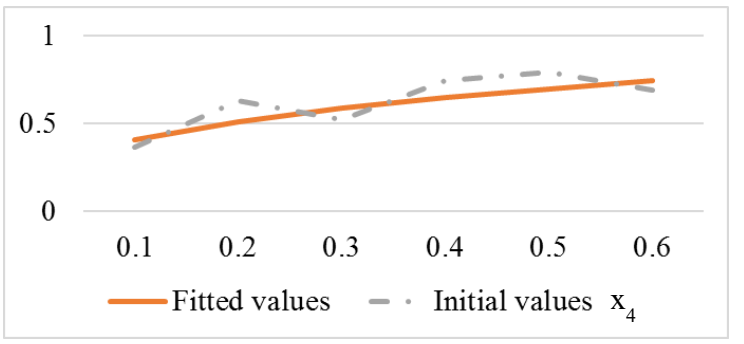

$b$

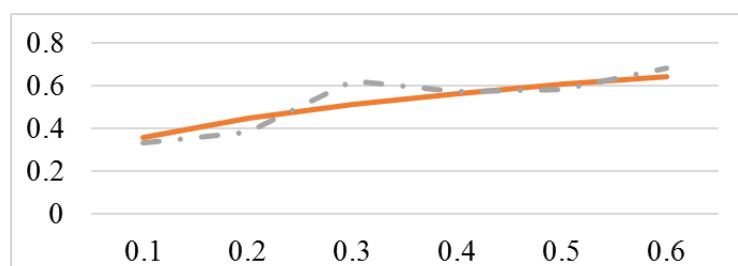

- Fitted values - Initial values $\mathrm{x}_{5}$ $c$

Fig. 3. Normalized values of indicators of physical potential of the region depending on the amount of funds from the budget

to a given direction: $a$ - the relative level of recovery and sports training; $b$ - the relative level of housing and communal services; $c-$ the relative level of environmental safety Note: compiled by authors using data from [19,20]

Model (3) belongs to the class of nonlinear models but its parameters can be obtained using its linearization and applying a method of the least-squares [12]. The calculation results are summarized in Table 2.

Table 2

Parameters of the models of the dependence of the level of physical potential on the amount of budget funds aimed at the development of the region

\begin{tabular}{|c|c|c|c|}
\hline \multirow{2}{*}{ Components of physical potential } & \multicolumn{2}{|c|}{ Model parameter } & \multirow{2}{*}{$\begin{array}{c}\text { Approxima- } \\
\text { tion error }\end{array}$} \\
\cline { 2 - 4 } & $a$ & $b$ & $7.3 \%$ \\
\hline morbidity rate of population $X_{1}$ & 0.87 & 0.33 & $12.8 \%$ \\
\hline $\begin{array}{c}\text { level of development of social } \\
\text { infrastructure } X_{2}\end{array}$ & 0.78 & 0.31 & $9.3 \%$ \\
\hline level of health and sports training $X_{3}$ & 0.81 & 0.3 & $12.6 \%$ \\
\hline $\begin{array}{c}\text { level of housing and communal } \\
\text { services } X_{4}\end{array}$ & 0.88 & 0.34 & $9 \%$ \\
\hline level of environmental safety $X_{5}$ & 0.76 & 0.33 & $9 \%$ \\
\hline
\end{tabular}

Note: Calculated by authors
Analysis of data from Table 2 allows us to conclude that all built models can be used in further research since the error rate is less than $15 \%$. The next step of this stage is to build similar dependences between the indicators of the potential of abilities and knowledge and budget funds (Fig. 4). A graphical representation of the relationship between budget expenditures and indicators of the potential of the population is shown in Fig. 5.

Based on the information above (Fig. 2,3), the most reliable and dense relation is observed between the components

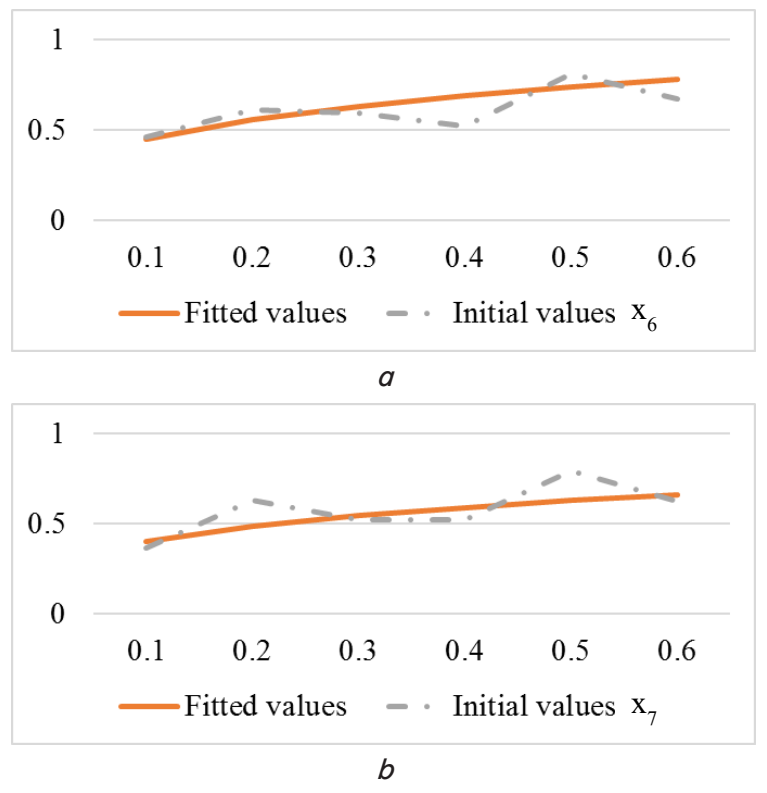

Fig. 4. Normalized values of indicators of the potential of abilities and knowledge of the region depending on the amount of funds from the budget in a given direction: $a-$ the relative level of education; $b-$ the relative level of culture Note: compiled by authors using data from [19,20]

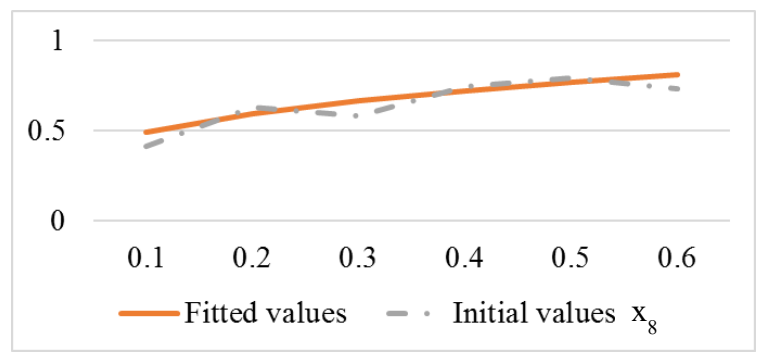

$a$

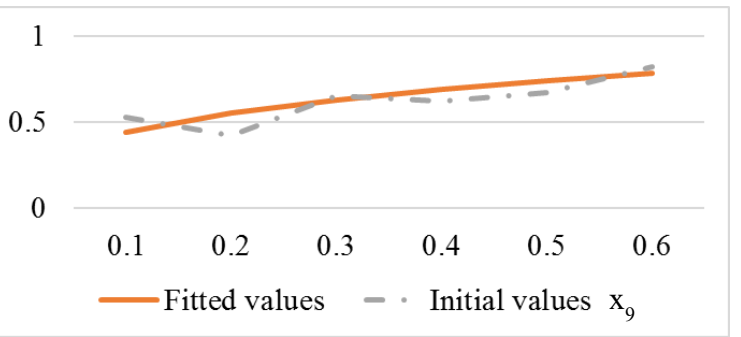

$b$

Fig. 5. Normalized values of indicators of the property potential of the region depending on the amount of funds from the budget in a given direction: $a-$ the relative level of remuneration and entrepreneurial income; $b-$ the relative level of social payments to the population

Note: compiled by authors using data from [19, 20] 
of the potential of abilities and knowledge and the property potential and the amount of budget expenditures for their provision. The established dependence can be described using a step function in the general form (3), which confirms the provision on the possibility of increasing to a certain extent the components of the potential at the expense of budget financing.

The results of building models and assessing their quality for the components of the potential of abilities and knowledge and the property potential are given in Table 3.

Thus, equations in the form of (3) and the established plots of functions (Fig. 1-3) allowed us to build functions $I_{i}$ which are universal for all components of the PLSP in a region.

Stage 3. Setting the criterion for optimization and the system of restrictions for the model of optimization of budget funds.

The value of the achieved level of development of PLSP in a region depends on the components discussed above and can be considered their linear combination.

Table 3

Parameters of the models of the dependence of components of the level of the potential of abilities and knowledge and the property potential on the amount of budget funds aimed at the development of the region

\begin{tabular}{|c|c|c|c|}
\hline \multirow{2}{*}{$\begin{array}{l}\text { Components of the potential of } \\
\text { abilities and knowledge and the } \\
\text { property potential }\end{array}$} & \multicolumn{2}{|c|}{ Model parameter } & \multirow{2}{*}{$\begin{array}{l}\text { Approxima- } \\
\text { tion error }\end{array}$} \\
\hline & $a$ & $b$ & \\
\hline level of education $X_{6}$ & 0.91 & 0.31 & $12.6 \%$ \\
\hline level of culture $X_{7}$ & 0.76 & 0.28 & $13.1 \%$ \\
\hline $\begin{array}{l}\text { level of wages and entrepre- } \\
\text { neurial income } X_{8}\end{array}$ & 0.93 & 0.28 & $9.2 \%$ \\
\hline $\begin{array}{l}\text { level of social benefits to the } \\
\text { population } X_{9}\end{array}$ & 0.92 & 0.32 & $12.8 \%$ \\
\hline
\end{tabular}

Note: Calculated by authors

Thus, when analyzing possible criteria for the PLSP level in the region, it is proposed to use a weighted additive criterion $(F)$, which takes the form:

$$
F=\sum_{i=1}^{m} \alpha_{i} I_{i}\left(y_{i}\right) \underset{y_{i}}{\rightarrow} \max
$$

where $\alpha_{i}$ is the coefficient of the relative importance of the $i$-th direction of the PLSP in a region, $\Sigma \alpha_{i}=1$.

To calculate the numerical values of the proposed coefficients, real authors consider it expedient to use a well-known approach based on expert assessments, which are pairwise comparisons of the importance of impact indicators on PLSP [17].

The results of using this approach are given in Table 4.

Based on the existing relationship between budget expenditures and PLSP indicators in the region and certain coefficients of the relative importance of its directions, as shown in Table 4, it is possible to solve the problem of effective allocation of the remaining budget funds. It is important to pre-calculate the mandatory part to achieve the required minimum value of each of the components of the PLSP in a region.

Taking into consideration the results of stage 2, the objective function (4) takes the following form:

$$
F=\sum_{i=1}^{m} \alpha_{i}\left(a_{i} \cdot y_{i}^{b_{i}}\right) \underset{y_{i}}{\rightarrow} \max
$$

Thus, we have the following optimization task: it is necessary to distribute limited budget funds (expression (1)) so that the PLSP level in the region is maximum - expression (5).

Stage 4. Solving the problem of nonlinear programming determining the share of budget expenditures for the development of PLSP in a region.

Tasks (5), (1) belong to the class of tasks of nonlinear programming. It should be added that the objective function (5) is additive, and its components are functions that are convex upwards. That is why, to solve the optimization problem (5), (1), one can use the method of sequential distribution, which makes it possible to obtain the optimal solution [16].

Therefore, the optimal allocation of budget funds takes the form given in Table 5 .

Stage 5. Determining the level of development of PLSP directions in the region, which can be achieved by changing budget expenditures.

Based on our results obtained from the model of optimization of budget funds in the Kharkiv region, it is necessary to form priority areas of budget financing for each component of the PLSP in the region.

Table 5

Optimal allocation of budget funds according to the components of the potential of life support of the population in the region

\begin{tabular}{|c|c|c|}
\hline \multicolumn{2}{|c|}{ Components of PLSP in a region } & \multirow{2}{*}{$\begin{array}{c}\text { Share of } \\
\text { Indicator }\end{array}$} \\
\begin{tabular}{c|c|c|} 
Pudget \\
level
\end{tabular} \\
\hline Components of physical potential \\
\hline morbidity rate of population $X_{1}$ & 0.32 & $4 \%$ \\
\hline level of social infrastructure development $X_{2}$ & 0.31 & $11 \%$ \\
\hline level of health and sports training $X_{3}$ & 0.33 & $4 \%$ \\
\hline level of housing and communal services $X_{4}$ & 0.32 & $3 \%$ \\
\hline level of environmental safety $X_{5}$ & 0.28 & $5 \%$ \\
\hline Components of abilities and knowledge potential \\
\hline educational level $X_{6}$ & 0.63 & $29 \%$ \\
\hline level of culture $X_{7}$ & 0.39 & $9 \%$ \\
\hline \multicolumn{2}{|c|}{ Components of property potential } \\
\hline level of wages and entrepreneurial income $X_{8}$ & 0.59 & $21 \%$ \\
\hline level of social benefits to the population $X_{9}$ & 0.5 & $14 \%$ \\
\hline
\end{tabular}

For the components of the physical potential, the optimal share of funds will be $27 \%$ of the share of budget funds, for the components of the potential of abilities and knowledge $-38 \%$, for the components of property potential $-35 \%$.

In addition, according to the results of optimization, it is necessary to significantly reduce budget expenditures on the level of morbidity of the population since these funds are not spent effectively and do not lead to an increase in the level of PLSP in the Kharkiv region.

Thus, the most priority areas are the components of the potential of abilities and knowledge and the property potential. However, if we consider in terms of individual indicators, the highest priority should be the level of professional training $(29 \%)$. Also important for the formation of the potential of life support of the population is the level of remuneration and entrepreneurial income $(21 \%)$, the level of social payments to the population (14\%), and the level of development of social infrastructure (11\%). 
Table 4

Coefficients of the relative importance of the components of the potential of life support of the population in the region

\begin{tabular}{|c|c|c|c|c|c|c|c|c|}
\hline $\begin{array}{c}\text { morbidity } \\
\text { rate of popu- } \\
\text { lation } X_{1}\end{array}$ & $\begin{array}{c}\text { level of } \\
\text { social infra- } \\
\text { structure } \\
\text { development } \\
X_{2}\end{array}$ & $\begin{array}{c}\text { level of } \\
\text { health and } \\
\text { sports train- } \\
\text { ing } X_{3}\end{array}$ & $\begin{array}{c}\text { level of } \\
\text { housing and } \\
\text { communal } \\
\text { services } X_{4}\end{array}$ & $\begin{array}{c}\text { level of en- } \\
\text { vironmental } \\
\text { safety } X_{5}\end{array}$ & $\begin{array}{c}\text { educational } \\
\text { level } X_{6}\end{array}$ & $\begin{array}{c}\text { level of wag- } \\
\text { level of } \\
\text { culture } X_{7}\end{array}$ & $\begin{array}{c}\text { es and entre- } \\
\text { preneurial } \\
\text { income } X_{8}\end{array}$ & $\begin{array}{c}\text { level of so- } \\
\text { cial benefits } \\
\text { to the popu- } \\
\text { lation } X_{9}\end{array}$ \\
\hline 0.07 & 0.11 & 0.06 & 0.08 & 0.06 & 0.19 & 0.11 & 0.18 & 0.14 \\
\hline
\end{tabular}

We shall analyze how the new allocation of budget funds could affect the level of PLSP in the Kharkiv region.

The actual data on the budget allocation by the components of the life support potential of the population in the region for 2021 were as follows:

$$
\begin{aligned}
& y_{1}=0.3 ; \quad y_{2}=0.06 ; \quad y_{3}=0.02 ; \\
& y_{4}=0.01 ; \quad y_{5}=0.01 ; \\
& y_{6}=0.24 ; \quad y_{7}=0.03 ; \quad y_{8}=0.2 ; \quad y_{9}=0.13 .
\end{aligned}
$$

The value of the objective function (5) was calculated for the actual data of the allocation of budget funds and compared to the optimal solution obtained. As a result, it was obtained that the optimal solution corresponds to the value of the PLSP level in the region by $9 \%$ more than with the actual distribution in the previous 2021.

The obtained values of the share of funds invested in each area of PLSP in the region are objective, taking into consideration the above coefficients of the relative importance directly (Table 4).

The proposed models could be used within the framework of a well-grounded scientific and practical approach to the formation of a methodology for the effective allocation of budget funds according to the indicators of PLSP in a region. This would help determine the share of expenditures of the regional budget, which are directed to a different area, which could increase the efficiency of their functioning (Fig. 6).

Based on the results obtained, it is advisable to form priority areas and choose areas of regulation and control of the development of life support potential in the region. Comparing the obtained optimal values of the share of budget funds for indicators of physical potential, it was found that it is advisable to redistribute budget expenditures in the following areas:

- development of social infrastructure;

- rehabilitation and sports training;

- ensuring environmental safety of the population;

- improving the quality of education of the population.

It should be noted that environmental safety is the most humane and responsible task of environmental legislation, which, firstly, embodies the environmental rights of Ukrainian citizens. Secondly, it guarantees the implementation of environmental safety and determines the legal, economic, and social foundations for the protection of the ecological environment [22]. Therefore, the function of implementing environmental policy at the regional level is to regulate the rational use of important regional natural resources. Another direction is the constant monitoring and accounting of natural resources at the regional level, control over compliance with environmental legislation, the formation of regional plans for the implementation of environmental measures, etc. [23].

\section{Determine optimal structure of budget expenditures characterizing the level of} the development of the potential of life support of population (PLSP) in a region

1. Acquire initial info on modeling the efficient allocation of budget finds
based on the PLSP indicators in a region

2. Build models of relationship between the values of indicators characterizing PLSP in a region and the amount of budget funds allocated for its development (graphical and tabular representation of results, their analysis and interpretation

Build a model of the dependence of PLSP components in a region on the amount of budget funds: $I_{i}=a \cdot y_{i}^{b}$,

where a i $\mathrm{b}$ - are model parameters

3. Define optimization criterion and a system of constraints for the model of
budget funds' optimization
budget funds' optimization

Amount of funds invested in the $i$-th area:

$$
P_{i}=y_{i} \cdot P_{b} \text {, }
$$

where $-P_{b}$ is the total amount of budget funds planned to invest in PLSP in a region $i=\overline{1, m}$

$$
\begin{aligned}
& \text { Weighted additive criterion: } \\
& \qquad F=\sum_{i=1}^{m} \alpha_{i}\left(a_{i} \cdot y_{i}^{b_{i}}\right) \underset{y_{i}}{\rightarrow} \max .
\end{aligned}
$$

where $-\alpha_{i}$ is the coefficient of relative importance of the $i$-th area of PLSP in a region,

$$
\Sigma \alpha_{i}=1
$$

4. Solve the problem of linear programming - determine the share of budget funds for the areas of PLSP development in a region

$$
\nabla
$$

5. Determine the level of development of PLSP in a region that can be achieved by changing budget funds

Formation of high-priority areas of budgetary financing of the areas of potential of life support of the population in a region (PLSP) and the choice of the sphere of regulation and control of regional development

Fig. 6. Scientific and practical approach to the formation of a methodology for the effective allocation of budget funds in terms of the potential of life support of the population in the region 
Solving problems related to the functioning of the social area is the prerogative of the state. Therefore, it is important to pay attention to the social measures of state bodies to rationalize expenditures in the social area (revision of benefits and the minimum wage, the subsistence minimum, the distribution of paid services). It is also worth achieving optimization of budget expenditures through self-financing [24]. Since the mechanism for granting benefits is not perfect benefits are not available to all people who are entitled to them but only to those who use the service [25].

There is no complete system of accounting for the services provided and the actual income of the family, which makes it difficult to provide assistance to those who need it. Therefore, tackling these issues requires additional measures, specifically: the revision of legislative and regulatory acts on social protection of the population and, on this basis, the adoption of relevant legislative and regulatory acts. It is advisable to establish social norms and standards for monitoring their observance, formulate plans for solving specific social problems (overcoming poverty, providing affordable educational and medical services, protecting the environment, etc.), monitoring their implementation [26].

Among the measures at the state and regional levels, important for optimizing budget expenditures are:

- organization of state control over the use of budget funds. Ineffective state control led to negative phenomena in the national economy. At the same time, before distributing financial assistance to different regions, it is necessary to check its previous use. If the use of financial assistance is ineffective, it is recommended not to provide assistance to such regions;

- approval of an effective budget: the state budget of Ukraine, unfortunately, became a reflection of the relevant views and interests of individual groups, due to imperfect management and the use of inefficient decision-making methods. The process of annual approval of the state budget is the subject of a compromise solution between different political forces, and not the search for the best solution to provide public goods with available resources with maximum efficiency;

- optimization of the composition of the performers of budget programs towards minimizing the number of performers of the task;

- improvement of budget and tax legislation in order to harmonize regulatory acts ensuring the balance of budget revenues and expenditures, minimizing the number of changes to existing laws during the budget period. Since public expenditures are "state in nature and are generated entirely in accordance with regulatory acts", the state should have effective legal norms and effective methods of regulating and managing the flows of public funds [26];

- according to the experience of many countries, the transition from budget planning to budget forecasting will provide opportunities for formulating strategic goals and determining methods for achieving them. This will make it possible to timely identify and eliminate shortcomings in budget policy [15, 25].

It should be noted that in accordance with the problems arising in the process of regional development, decisions must be made immediately, and the list of actions can be supplemented and updated. The implementation of the proposed actions will contribute to the optimization of budget expenditures. It will also make it possible to form and implement a balanced financial and budgetary policy, which will take into consideration the positive experience of the leading countries of economic development, which will make it possible to form prerogative items of public spending. Financing of certain areas and objects of state regulation for each component of PLSP in a region makes it possible to create prerequisites for development, including entrepreneurial activity. The formation on this basis of an adequate strategy for the development of enterprises in the region will ensure the achievement of the synergy effect in the field of budget and tax management. The implementation of such measures is possible subject to the unity of the objective function for each element of PLSP in a region and the systematic improvement of functional connections.

\section{Discussion of results of analyzing and modeling the policy of allocation of budget funds under the budget and tax management}

Our seminal results are explained by the fact that the rational allocation of budget funds is ensured by the maximum possible approximation of the PLSP indicators in the study region to the "ideal" state at the achieved level of development (Fig. 2-4, Tables 2-4).

Thus, the results of the analysis and modeling of the policy of distribution of budget funds according to the indicators of PLSP in a region showed that the highest priority area is the level of professional training (29\%). Next in importance is the level of development of social infrastructure (11\%), the level of remuneration and entrepreneurial income (21\%), and the level of social payments to the population (14\%). The amount of the achieved level of development of PLSP in a region, subject to the new distribution of budget funds, could increase by $9 \%$ compared to 2021 .

The main advantages of our study are that the model of allocation of budget funds according to the indicators of PLSP in a region allowed us to substantiate and develop practical recommendations for improving the efficiency of management of local budget expenditures. Specifically, priority directions of budget financing of certain spheres and objects of state regulation for each component of the PLSP in a region were formed, taking into consideration the coefficients of the relative importance of a given area (Table 3 ).

It is established that the redistribution of budget expenditures should be carried out in the following areas: the development of social infrastructure; rehabilitation and sports training; ensuring environmental safety of the population, and improving the quality of education of the population.

The limitations of the original study include the need to obtain and take into consideration reliable data in the diagnosis of the distribution of budget funds and the effectiveness of their use. Since corruption is a problem for many countries of the world, specifically local authorities, the lack of transparency in the processes of allocation of budget resources do not make it possible to carry out an adequate assessment of the potential for life support of the population.

The disadvantages of the proposed approach include the use of expert assessments to characterize the importance of the components of the potential for life support of the population in the region. It is well known that their use limits the subjectivity of expert opinions and the inertia of their judgments but this can be corrected by a qualitative selection of experts and the choice of appropriate methods for processing expert assessments. 
A prospect of using the results of this study, we point to the solution of the non-trivial problem of forming the socio-economic potential of the country, specifically its regions. For this purpose, not only modern tools for analyzing and modeling the policy of distribution of funds for the implementation of justified universal measures of purposeful influence in the field of budget and tax management are used. An effective mechanism for distributing limited budget funds between priority areas of budget financing of area and objects is also being formed, which requires qualitative transformations at the strategic and tactical level of management decision-making.

\section{Conclusions}

1. The main strategic resource of the country, specifically its regions, is human potential, which has a set of characteristics that reflect its physical potential, the potential of abilities and knowledge, the property potential. On this basis, a methodical approach to the definition of PLSP in a region is proposed, based on the principles of the anthropocentric approach, which makes it possible to freely choose the directions of human realization of one's own potential. Indicators for assessing PLSP in a region form three groups, which include different components of the potential. The difference between this approach is its use as a tool for studying the resources of the region in terms of their ability to meet the needs of the population of the region in the current period and in the future.

2. As a result of the analysis of the list of underfunded items of budget expenditures (social security, education, etc.), it was established that those areas that may contribute to the future filling of the budget are characterized by a limited amount of financial resources. The expediency of permanent improvement of distribution policy by an insufficient amount of budget funds as a problem of mathematical programming is substantiated. Solving it has made it possible to synthesize a new toolkit for the implementation of management activities and to reveal the depth of state interference in economic processes in the performance of its economic and social functions in the direction of ensuring the development of the region.
A comprehensive integrated model for determining the optimal structure of budget expenditures and their impact on the dynamics of development of the potential for life support of the population of the region is proposed. Assessment of the level of impact of budget expenditures on indicators of the potential of life support of the population of the region based on quantitative and qualitative measurement of it formed an information base for making management decisions in the field of budgetary relations.

It should be noted that the results of the calculations proved the adequacy of the proposed model of effective distribution of budget funds according to the indicators of PLSP and can be used in the development of strategic and medium-term plans for the development of regions. The formation of corrective managerial influences in determining the economic priorities of the region should be carried out taking into consideration the relative importance of the directions. This makes it possible to assess the effectiveness of the impact of decisions of local self-government bodies on the target components of the PLSP in a region and to choose priority areas of budget financing for each component.

The results of the analysis and evaluation of the policy of allocation of limited resources through the prism of ensuring the improvement of life support of the population in the region contribute to the development and implementation of targeted comprehensive programs aimed at solving urgent problems. Improving the efficiency of distribution of budget funds according to the indicators of PLSP in a region makes it possible to modernize the infrastructure of regional development, creates the basis for increasing the investment attractiveness of the region, and the introduction of innovative technologies, etc.

\section{Acknowledgments}

We express our sincere gratitude to Doctor of Economics, Professor Viktor Zaruba, and Doctor of Technical Sciences, Professor Lev Raskin, whose professional consultations have made a significant contribution to understanding the processes under study and solving these problems.

\section{References}

1. United Nations Development Programme. Human Development Reports. Available at: https://hdr.undp.org/

2. Bluedorn, J., Lian, W., Novta, N., Timmer, Y. (2019). Widening Gaps: Regional Inequality within Advanced Economies. International Monetary Fund. Available at: https://blogs.imf.org/2019/10/09/widening-gaps-regional-inequality-within-advanced-economies

3. Shevchenko, O. V. (2020). Dysproportsiyi sotsialno-ekonomichnoho rozvytku rehioniv Ukrainy: sutnist, otsinka, stratehichne rehuliuvannia. Kyiv: NUOU, 300. Available at: https://niss.gov.ua/sites/default/files/2020-09/monografiya-anotaciya.pdf

4. Shevchenko, O. V., Bakhur, N. V., Maliarevskyi, Ye. V., Deshko, A. L. (2021). Optymizatsiya vydatkiv biudzhetu na sotsialnoekonomichnyi rozvytok okremykh terytoriy. Natsionalnyi instytut stratehichnykh doslidzhen. Available at: https://niss.gov.ua/ sites/default/files/2021-01/subventsii.pdf

5. Gajdova, K. (2016). Regional Disparity in Selected Regions of the Czech Republic - With New Definition. International journal of economics and statistics, 4, 161-165. Available at: https://www.naun.org/main/NAUN/economics/2016/a482015-054.pdf

6. Moldovan, O. O., Bila, S. O., Shevchenko, O. V., Kushnir, M. O., Tyshchuk, T. A., Miedviedkova, N. S. (2012). Biudzhetna polityka v Ukraini v umovakh ryzykiv spovilnennia ekonomichnoi dynamiky. Kyiv: NISD, 80. Available at: http://old.niss.gov. ua/content/articles/files/Moldavan_budget-3b073.pdf

7. Donos, L., Ploskyi, K. (2019). Uprovadzhennia ta vdoskonalennia Hromadskoho biudzhetu: praktychni rekomendatsiyi. Available at: https://decentralization.gov.ua/uploads/library/file/485/Public_Budget_2019.pdf

8. Martínez-Galarraga, J., Rosés, J. R., Tirado, D. A. (2013). The Long-Term Patterns of Regional Income Inequality in Spain, 18602000. Regional Studies, 49 (4), 502-517. doi: https://doi.org/10.1080/00343404.2013.783692 
9. Khutkyi, D., Avramchenko, K. (2020). Otsinka vplyvu biudzhetu uchasti v Ukraini. Kyiv, 50. doi: https://doi.org/10.13140/ RG.2.2.35795.32804

10. Biudzhetna polityka derzhavy v umovakh hibrydnoi viyny: priorytety ta ryzyky (2020). Natsionalnyi instytut stratehichnykh doslidzhen. Kyiv: NISD. Available at: https://niss.gov.ua/sites/default/files/2017-11/biudzh_polit-6c509.pdf

11. Makarenko, O. I., Zulfuharova, S. O. (2008). Model optymizatsii rozpodilennia biudzhetnykh koshtiv. Ekonomichna kibernetyka, 1-2 (49-50), 38-41.

12. Maliarevskyi, Ye. V., Barannik, V. O. (2021). Hromadski biudzhety yak perspektyvnyi instrument rozvytku hromad i terytoriy. Natsionalnyi instytut stratehichnykh doslidzhen. Kyiv: NISD. Available at: https://niss.gov.ua/sites/default/files/2021-11/ hromadski-budzhety.pdf

13. Pro skhvalennia Stratehiyi reformuvannia systemy upravlinnia derzhavnymy finansamy na 2017-2020 roky. Rozporiadzhennia Kabinetu Ministriv Ukrainy vid 08.02.2017 r. No. 142-p. Available at: https://zakon.rada.gov.ua/laws/show/142-2017-\%D1\%80?lang=uk\#Text

14. Program budgeting is on the reform Agenda across Europe and Central Asia. (2020). Available at: https://blog-pfm.imf.org/ pfmblog/2012/05/program-budgeting-is-on-the-reform-agenda-across-europe-and-central-asia.html

15. EU Budget for the Future. Available at: https://ec.europa.eu/info/sites/info/files/factsheet-eu-budget-financing_.pdf

16. Raskin, L., Sira, O. (2020). Development of modern models and methods of the theory of statistical hypothesis testing. EasternEuropean Journal of Enterprise Technologies, 5 (4 (107)), 11-18. doi: https://doi.org/10.15587/1729-4061.2020.214718

17. Zaruba, V. Ya., Potrashkova, L. V. (2019). Realizatsiya imitatsiynoi modeli otsiniuvannia stratehichnoho potentsialu pidpryiemstva. Instrumental'nye sredstva modelirovaniya sistem v informatsionnoy ekonomike. Bratislava; Kharkiv: VShEM: KhNEU, 207-219. Available at: http://repository.kpi.kharkov.ua/handle/KhPI-Press/48899

18. Raskin, L., Sira, O. (2018). Multi-criteria optimization in terms of fuzzy criteria definitions. Mathematical Modeling and Computing, 5 (2), 207-220. doi: https://doi.org/10.23939/mmc2018.02.207

19. State Statistics Service of Ukraine. Available at: http://www.ukrstat.gov.ua/

20. Main Department of Statistics in Kharkiv Region. Available at: http://kh.ukrstat.gov.ua/

21. Indeks infliatsiyi v Ukraini 2010-2020 rr. Available at: http://www.ukrstat.gov.ua/operativ/operativ2006/ct/cn_rik/isc/isc_u/isc_m_u.htm

22. Kuzmynchuk, N., Kivalov, S., Tarasenko, V., Voloshyna, S., Chanyshev, R., Shchukin, O. (2021). Ecological safety of the region`s population in the aspect of the logistic-activity approach to its formation and legal regulation. IOP Conference Series: Earth and Environmental Science, 915 (1). doi: https://doi.org/10.1088/1755-1315/915/1/012027

23. Kuzmynchuk, N., Kutsenko, T., Nazarova, T., Druhova, E. (2017). Analyses dynamics of taxpayers behavior fating the influence of social-psychological factors. Problems and Perspectives in Management, 15 (3), 98-107. doi: https://doi.org/10.21511/ ppm.15(3).2017.08

24. Robinson, M. (2013). Program classification for performance-based budgeting: how to structure budgets to enable the use of evidence. The World Bank. Available at: https://ieg.worldbankgroup.org/sites/default/files/Data/reports/performance_based_budgeting_bb.pdf

25. The European Council and the 2021-27 Multiannual Financial Framework. Available at: https://www.europarl.europa.eu/ RegData/etudes/BRIE/2020/631732/EPRS_BRI(2020)631732_EN.pdf

26. Pro Stratehiyu staloho rozvytku Ukrainy do 2030 roku. Proiekt Zakonu Ukrainy vid 07.08.2018 r. No. 9015. Available at: http:// search.ligazakon.ua/__doc2.nsf/link1/JH6YF00A.html 